\title{
Intellectual Capital (Intangible Assets) Valuation Considering The Context
}

Miguel Angel Axtle Ortiz, (E-mail: maxtle@global.t-bird.edu), Universidad Anáhuac México Sur, Mexico

\begin{abstract}
This article seeks to illustrate the evolution of intangible assets studies to the broader concept of intellectual capital and its valuation methods; then clarifies misunderstood concepts about the existence of intangible liabilities. A systemic dynamics approach to the IC valuation method considering the context finally is explained.
\end{abstract}

\section{INTRODUCTION}

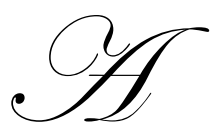

Intangibles are all around the business world. What intangible assets are, have been under a lot of study for more than forty years and still there is no generally accepted approach on how to measure their value or what makes them to increase or decrease. In the need of a known reference to build the theory for intangibles, the accounting theory analogies are still being made even though the intangible asset concept has evolved to a broader one, intellectual capital (IC). IC still uses an accounting terminology but is studied by a managerial approach.

The presence of an accounting terminology confuses sometimes and allows still trying to explain its behavior from an accounting point of view. That is why concepts like intangible liabilities and intangible capital or equity have appeared trying to explain variations in the intangibles value. It should be considered that IC might not vary because of the existence of intangible liabilities but due to the context where they interact.

\section{INTANGIBLE ASSETS AND THE EVOLUTION TO INTELLECTUAL CAPITAL}

Intangibles valuation have been a concern since the mid 60's. Hermanson (1964) used the term "human asset accounting" trying to measure the value of the company's workers and incorporate that value to financial statements. By not being owned by the business, human assets differed from other categories present in financial statements. He dismissed that approach and concluded that the main difficulty lay in identifying an appropriate model for valuing such assets.

Flamholtz (1971) coined the term "Human resources accounting" and he regarded it to provide management information. He emphasized management rather than accounting to be what should be interested in human resources.

Intangibles research has been relevant to management since then because there is the awareness that persons, their knowledge and abilities are of great importance for the competitive advantage of the organizations.

In 1991 Skandia Assurance and Financial Services, a subsidiary of the Swedish Skandia Group appointed Leif Edvinsson as the first Director of Intellectual Capital. Edvinsson (1997) defined Intellectual Capital as:"The possession of knowledge, applied experience, organizational technology, customer relationship and professional skills that provides AFS with a competitive edge in the market" AFS represents Intellectual Capital as the difference between market value and its book value. 
Since then the intellectual capital term has been used to group all intangible assets. As stated before it is a management "terminology" and has little relation to what "capital" is understood in accounting. So there is no need to satisfy the assets = liabilities + capital equation and therefore Intellectual Capital does not need to be equal to intellectual assets - intellectual liabilities nor intangible assets - intangible liabilities. This would be explained later in this paper.

Stewart (1997) used the terms human capital, structural capital and customers' capital. Human capital has as main purpose thinking and innovating processes, it doesn't belong to the organization and it is lost when employees leave. Structural capital belongs to the organization. It can be reproduced and shared as technology, inventions, data, publications, strategy, organizational culture, structures, procedures and systems. Clients' capital is composed by relations between the clients and the organization, customer retention, profit and lose per client.

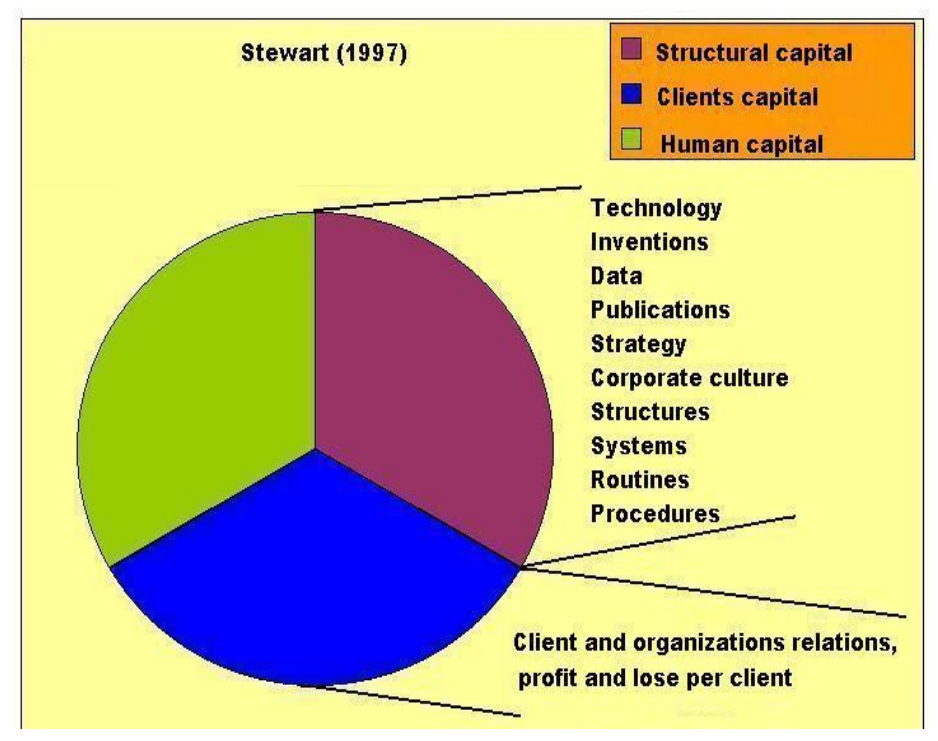

Sveiby (1997) divided intellectual capital in three parts. First employees` competences, second internal structure and third external structure. The first is ability of acting in a variety of situations to create tangible and intangible assets using their experience and education. Internal structure consists of patents, concepts, models and IT systems. The external structure includes relations with clients and suppliers. It includes brands, reputations and images. 


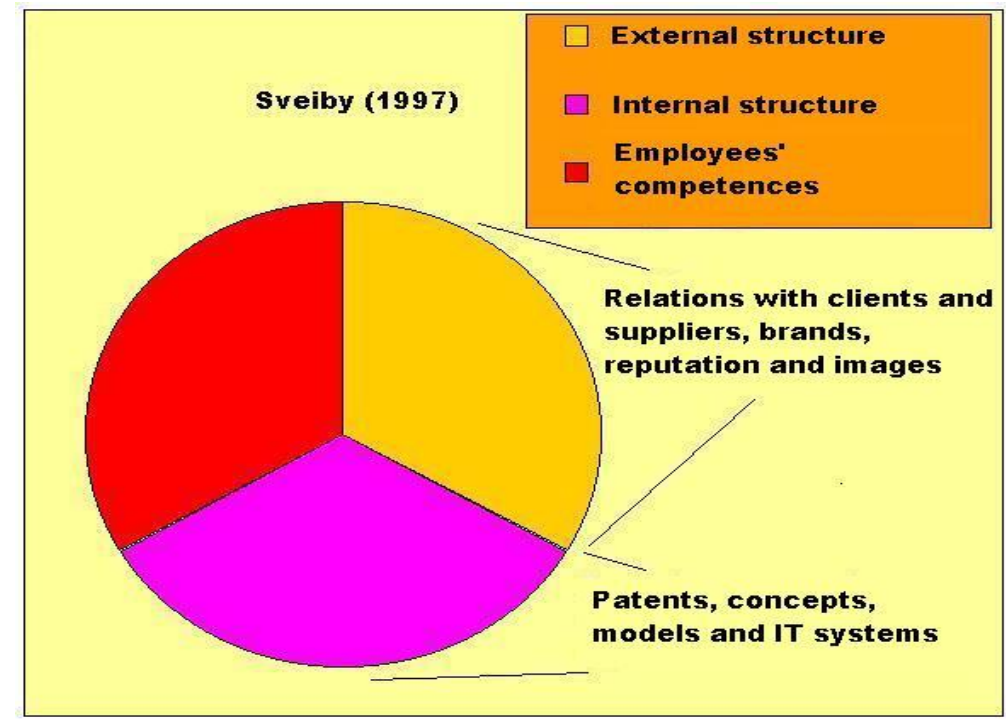

Edvinsson and Malone (1997) identified human capital and structural capital as intellectual capital components. The first include employees' knowledge, skills and innovation along with the company's values, culture and philosophy. Structural capital is everything else that improves productivity like hardware, software, databases, organizational structure, patents and trademarks.

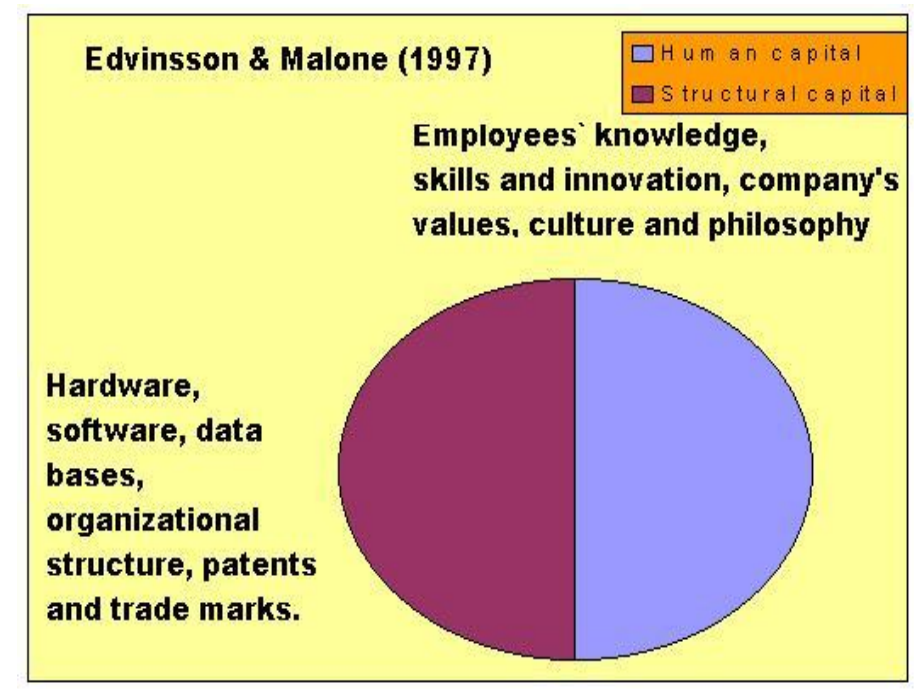

Anne Brooking (1996) classified intellectual capital in: market assets, assets cantered on humans, intellectual property and infrastructure assets. Market assets consists in the potential that an organization has due to intangibles related to the market that gives a competitive advantage like clients' loyalty, brands, distribution channel, contracts and advertisement. Assets centered on humans are composed by experience, creativity, solving problems ability, leadership, entrepreneurship, and management skills such as psychometric data and to perform under great stress. Infrastructure assets are technology, methodologies, corporate culture, hedging, data cases, communication systems, etc. Intellectual property is know-how, trade secrets, trademarks, patents and design rights. 


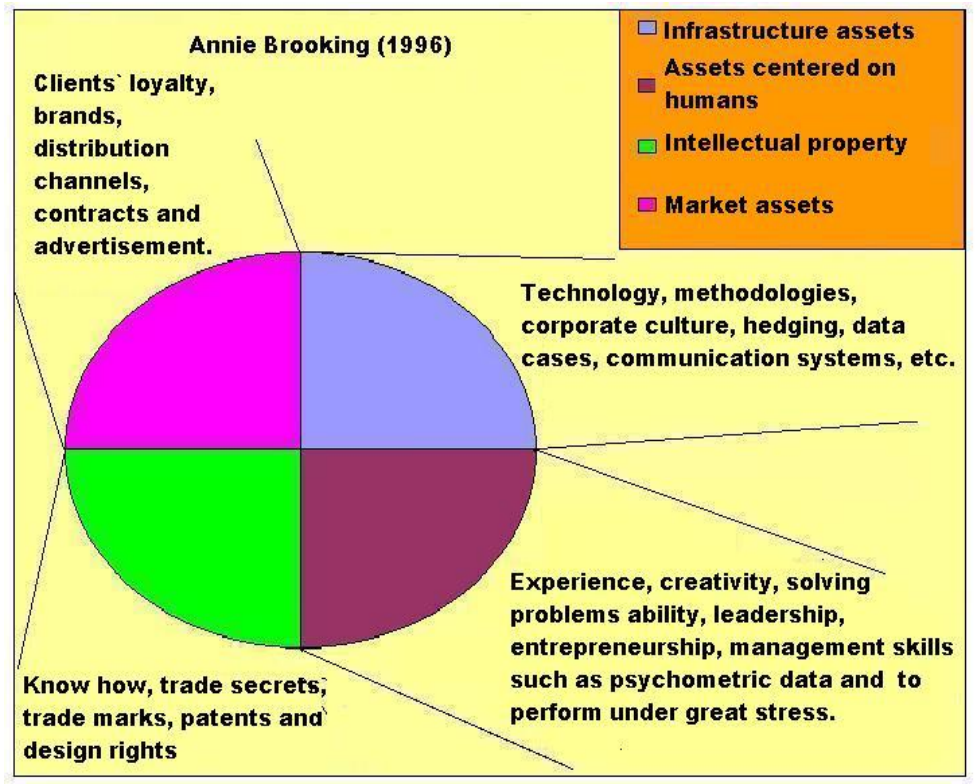

\section{INTELLECTUAL CAPITAL VALUATION METHODS}

Some of the methods to valuate intellectual capital are:

Return over Assets (ROA) uses the average pre-tax earnings of a company for three to five years. This average earning is then divided by the average tangible assets of the company over the same period of time. The resulting ROA is compared with the company's industry average to calculate the difference. If this difference is zero or negative, the company does not have an excess of intellectual capital over its industry average. So the value of intellectual capital is assumed to be zero. If the difference between the company's ROA and its industry average is positive, then the company is assumed to have excess intellectual capital over its industry.

This excess ROA is then multiplied by the firm's average tangible assets to calculate an average annual excess earning. Dividing this excess earning by the company's average cost of capital, one can derive an estimate of the value of its intellectual capital.

Market Capitalization Method (MCM) is based on the capital markets premium. This method reports the excess of a company's market capitalization over its stockholders' equity as its intellectual capital. To more accurately calculate MCM, the historical financial statements must be adjusted for the effects of inflation or replacement costs. Using historical data may distort the measurement, particularly in industries with large balances of old capital assets such as steel companies.

Direct Intellectual Capital Method (DIC) is based on measuring the value of intellectual capital by first identifying its various components. Once these components are accurately identified, they can be directly evaluated. It focuses on components of market assets such as customer loyalty, intangible assets, such as patents, technology assets such as know-how, human assets such as education and training, and structural assets such as information systems. Once these components are all measured, they can be aggregated to derive the total value of a company's intellectual capital.

Knowledge Capital Earnings (KCE). Proposed by Baruch Lev (2001) first one needs to normalize earnings 3 years before and the forecast for 3 years after. Subtracting the income caused by intangibles from the normalized earnings there is a portion of non-accounted earnings. This amount represents knowledge capital earnings and can be 
used for different ratios such as intellectual capital margin $\mathrm{KCE}$ / sales, and operative knowledge capital margin $\mathrm{KCE} /$ net income.

The multiple linear regression model proposed by Nevado and López (2002) of the following form:

\author{
$\mathrm{MCM}=\mathrm{X} 1 *\left(\mathrm{CH}^{*} \mathrm{iH}\right)+\mathrm{X} 2 *\left(\mathrm{CP} *_{\mathrm{i}} \mathrm{P}\right)+\mathrm{X} 3 *(\mathrm{CC} * \mathrm{iC})+\mathrm{X} 4 *\left(\mathrm{CM} *_{\mathrm{i}} \mathrm{M}\right)+\mathrm{X} 5 *(\mathrm{CI}+\mathrm{D} * \mathrm{iI}+\mathrm{D})$
}

Where:

- $\quad$ MCM is the market capitalization method (market value-book value).

- $\quad \mathrm{C}$ are absolute monetary indexes related to investments done in some of the 5 following fields:

- $\quad$ HC Human Capital (Salaries + Training investments)

- PC Processes Capital (preventive maintenance investments + Evaluation investments + Facilities investments)

- $\quad$ CC Commercial Capital (Investments to customers + Outsourcing Investments)

- $\quad$ CM Communicational Capital (Marketing Investments)

- $\quad$ CI+D Innovation Capital (Research investment + Patent investments + Software and hardware investments)

- $\quad i$ is an efficiency average of the above

- $\quad$ As an example iH contains the following efficiency indicators: market quota, 1-(salaries/sales), social action index, 1-(temporal employees/plant employees), 1-resigned+fired/\#employees), motivation index, promotions/\# of positions.

- The model does not assign monetary values to the IC components; it is based on efficiencies and investments.

- $\quad$ It could be useful to explain how IC behaves as well as the interaction and significance of every factor.

Tobin's $q$ compares the market value of an asset with its replacement cost. If $q$ is less than 1 then it isn't probable that a company would buy more assets of that kind. If an asset were worth more than its replacement cost, the company would invest in a similar asset. It is a cost based approach.

Economic Value Added (EVA) measures the monetary surplus value created on an investment. It is calculated using the following formula: EVA $=($ Return on Capital - Cost of Capital) $($ Capital Invested in Project)

Balance Scorecard is a management system that balances the financial perspective considering internal business processes and external outcomes of the business. Developed by Kaplan and Norton (1996) they described it as: "The balanced scorecard retains traditional financial measures. But financial measures tell the story of past events, an adequate story for industrial age companies for which investments in long-term capabilities and customer relationships were not critical for success. These financial measures are inadequate, however, for guiding and evaluating the journey that information age companies must make to create future value through investment in customers, suppliers, employees, processes, technology, and innovation." The Balance Scorecard considers the customer, financial, internal business processes and the learning and growth perspectives combined with the company's vision and strategy.

\title{
THE NATURE OF LIABILITIES AND THE MISCONCEPTION OF INTANGIBLE LIABILITIES
}

The recent interest of understanding the possible existence of intangible liabilities makes necessary to start from the basics and clarify terminologies.

In accounting a liability is a claim on the assets (therefore decreasing its value) of a company or individual excluding ownership equity. It represents a transfer of assets or services at a specified or determinable date. The firm or individual has little or no discretion to avoid the transfer. Liabilities represent what the business owes to another person or entities known as creditor and it is also possible that the event causing the obligation has already occurred. 
Trying to compare the management term "Intellectual Capital" to the accounting "capital" or "equity" term and applying the Intellectual Capital =Intellectual Assets-Intellectual Liabilities analogy is a misunderstanding of the Intellectual Capital=Intangible Assets concept and evolution explained before.

It would also be a concept misinterpretation trying to explain the decrease of an intangible asset value due to the existence of an intangible liability by the simple inexistence of a creditor that would receive the intangible assets transferred.

The intangible asset variation value is better explained by an appreciation or depreciation due to the context (market forces, speculation, etc) and the effective or ineffective use/management of them. When concepts like bad public image, bad word-of-mouth, weak strategic planning processes, dangerous work conditions, potential environmental cleanup, potential product tampering or poor corporate reputation are tried to be considered as intangible liabilities it should be noticed that they are only the ineffective use of the intangible asset in some cases and in others are only potential expenses, but in any case a creditor would exist. Neither potential expenses nor ineffective asset use should be considered as intangible liabilities because they differ in their nature. It is understandable that as in accounting the two reasons why an asset varies its value are liabilities and expenses, an analogy for intangible assets might work too, but it doesn't.

Then, what could be considered as an intangible liability? An immaterial payment promise, which decreases the value of the intangible assets by giving part of them to a creditor.

\section{CONTEXT, THE SOURCE OF INTANGIBLES VALUE VARIATION}

From a managerial point of view, is possible to address the variation issue considering the context where interrelated conditions occur. It should be considered that as in many other assets, the valuation of an intangible is a matter of perception. Some of the components of the intellectual capital are rational, directly measurable, but others are of an affective and perceptive nature.

The importance of context when valuating IC has been briefly suggested in papers by Rodov and Leliaert (2002). They expressed that management should assign the values they considered appropriate to IC according to the company. Also Chaminade and Johanson (2003) addressed the perception difference regarding to knowledge management in two different companies at two different European countries

Context should involve time (when the value of IC is measured) and location (depending on the region IC will vary). As tangible assets, the components' value of IC will vary depending on the moment and the region where they are. Some assets are more valuable in one region (state, country, hemisphere, etc.) than in other due to perception, resources, supply, demand, fashion, etc. Even for companies with almost everything equal if they are in different regions, the IC value will vary.

So far, the usual method to assign a value for an intangible and identify its variation has been a financial/accounting linear approach, which doesn't consider the interaction of all the variables that include intangibles, tangibles and the context. It is necessary to address the problem as a dynamic complexity where all the parts interact. Quantitative and qualitative models are needed to understand the behavior of intangibles and their valuation as a change in one part of the system affect the whole system.

IC fits the description of a system, which is a collection of parts organized for a purpose. The purpose of IC is the same as any other asset, to be a source of future benefits with the only difference that has no physical existence. IC as any other system, again, sometimes fails to achieve its purpose due to a lack of proper interaction, design or external disturbance. That is why IC value variations exist.

In figure 5 is shown from a system dynamics point of view how the different identified components of IC interact with each other's as a system and how the context constantly interacts as an input/output source, also as part 
of the system. The context constantly affects each and every IC component causing disturbances and affecting the total value.

\section{Conclusion}

Intellectual Capital studies will continue evolving until a generally accepted method is adopted due to the importance of knowing how and what makes intangibles to increase or decrease its value. Knowing the source of IC and why it varies will help management to take decisions and set strategies through the development of their intangibles.

Even though there are many methods trying to give an answer to the real economic value of IC, non of them is considering the context and most of them try to explain the phenomenon from a linear and accounting point of view without considering that culture, perception, feelings and a whole system is involved.

Businesses are not managed in an isolated environment and the context plays an important role. Then, the context should appear in the models that seek to represent reality. It is more difficult, but is not an irrelevant factor that simply can be dismissed.

\section{References}

1. Brooking, A. (1996). Intellectual Capital. 1st Ed. Nueva York: International Thomson Business Press.

2. Caddy, I. (2000); Intellectual capital: recognizing both assets and liabilities, Journal of Intellectual Capital, Vol. 1, No. 2, 2000, p129-146.

3. Chaminade, C. y Johanson, U. (2003). Can guidelines for intellectual capital management and reporting be considered without addressing cultural differences? Journal of Intellectual Capital. Bradford: 2003. Vol. 4, Iss. 4 ; p. 528.

4. Chen, J., Zhu, Z., Xie, H.Y. (2004). Measuring intellectual capital: a new model and empirical study. Journal of Intellectual Capital. Bradford: 2004. Vol. 5, Iss. 1; p. 195 (18 pages).

5. $\quad$ Edvinsson, L. (1998). El capital intellectual. México: Norma.

6. Edvinsson, L., Malone, M., (1997). El Capital Intelectual, Nueva York: Harper Collins.

7. Edvinsson, L, Congreso Internacional de Desarrollo Organizacional y Capital Humano, Liderando la Economía del Conocimiento a través del Capital Humano. (2004), Navegando en la Economía del Conocimiento, Monterrey, Nuevo León. México: Congreso y entrevista. 22 de octubre de 2004.

8. Fernández, Pablo (2001). Valuation of Brands and Intellectual Capital. IESE's Working Papers.May 29.

9. Fitz-enz, J. (2000). The ROI of Human Capital: Measuring the Economic Value of Employee Performance. [s.l.]American Management Association AMACOM.

10. Flamholtz, E.G. (1971), A model for human resource valuation: a stochastic processwith service rewards, The Accounting Review, April 253-267

11. Hermanson, R.H. (1964) Accounting for Human Assets, Occasional Paper No. 14, Division of Research, Graduate School of business Administration, Michigan State University, 4-5.

12. Kaplan R.S. and Norton D.P. (1996) The Balanced Scorecard: Translating Strategy Into Action. Boston: Harvard Business School Press.

13. Lev, B. Defining intellectual capital. Internet. 21/09/04 www.financialexpress.com/fe/daily/20000223/ffe22095.html

14. Lev, B. (2001). Intangibles: Management, Measurement, and Reporting Brookings Institute

15. Liebowitz, J. (1999). Knowledge management handbook [s.1.] CRC Press.

16. Nevado, D. y López V. (2002). El capital intelectual: Valoración y medición. Madris: Pearson educación.

17. Poole, D.V., Abdolmohammadi, M.J., Greenlay, L. Accounting methods for measuring intellectual capital Internet. 21/09/04 www.accountancysa.org.za/archives/1999mar/features/methods.htm

18. Robin R. (2000). Accountinng For Intellectual Capital: A contemporary Management Accounting Perspective. Management Accounting.

19. Rodov, I. y Leliaert, P. (2002). FiMIAM: financial method of intangible assets measurement. Journal of Intellectual Capital Volume: 3 Number: 3 (pp. 323 - 336). 
20. Roos, J., Roos, G., Dragonetti, N.C., Edvinson, L. (2001). Capital intellectual: el valor intangible de la empresa. Buenos Aires: Paidos Empresa.

21. Sveiby, K.E. (1997). The New Organizational Wealth. USA: Berett-Koehler Publishers

22. Stewart, T. (1997). Intellectual Capital. New York: Currency/Doubleday

23. Stewart, T. (2001). La Gestión del Concimiento y el Capital Intelectual. Buenos Aires: Granica.

24. Tissen, R., Andriessen, D. y Lekanne Deprez, F. (2002). El Valor del conocimiento para aumentar el rendimiento de las empresas. Madrid: Financial Times-Prentice Hall.

25. Tomer, J.F. (2003). Personal capital and emotional intelligence: An increasingly important intangible source of economic growth. Eastern Economic Journal. Bloomsburg: Summer 2003. Vol. 29, Iss. 3; p. 453.

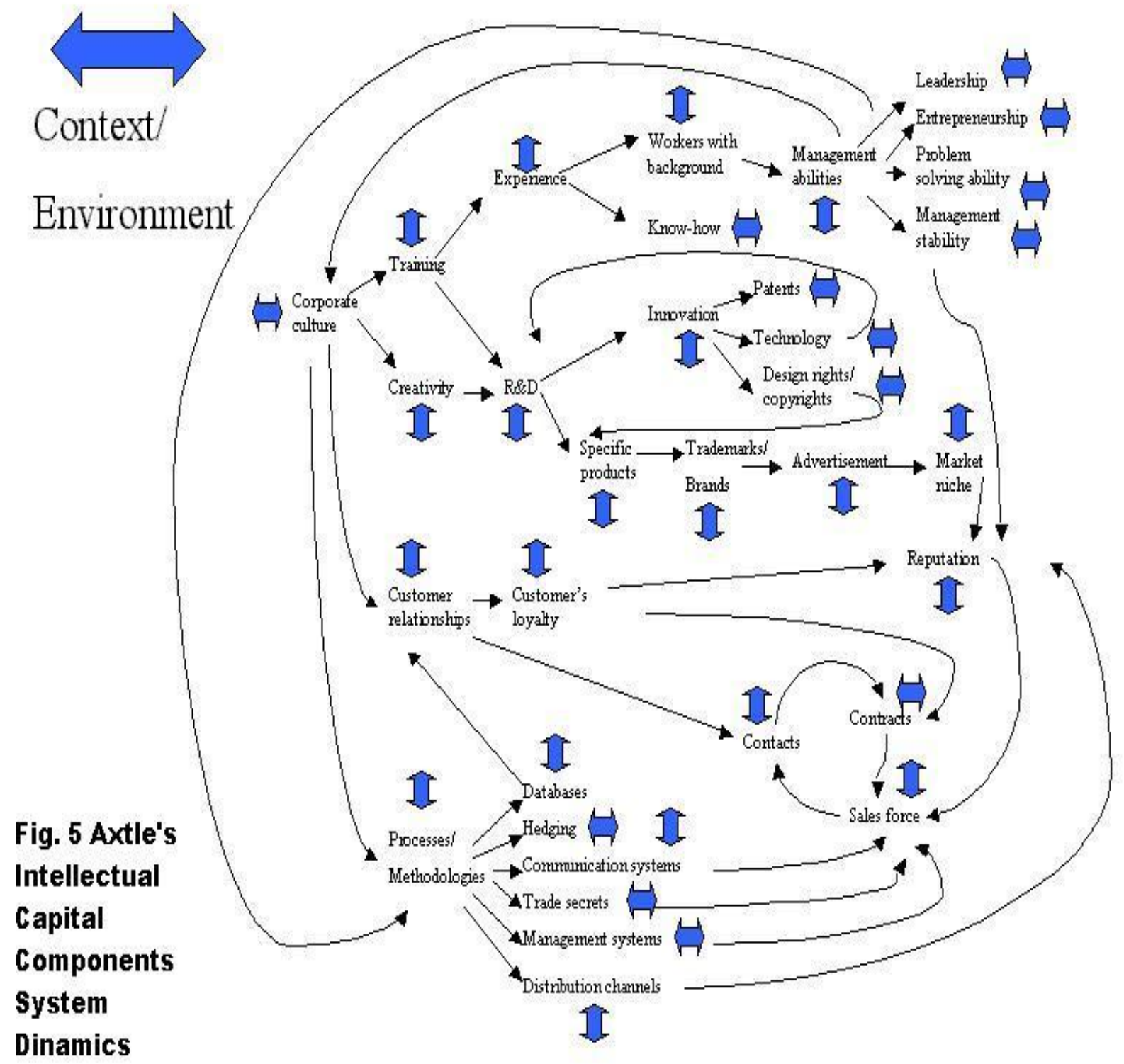

